\title{
Changes of Estuarine Sedimentation Patterns by Urban Expansion: The Case of Middle Capibaribe Estuary, Northeastern Brazil
}

\author{
Roberto Lima Barcellos ${ }^{1}$, Rubens César Lopes Figueira², Elvis Joacir França ${ }^{3}$, \\ Carlos Augusto Schettini', Diego de Arruda Xavier ${ }^{1 *}$ \\ ${ }^{1}$ Departament of Oceanography, Federal University of Pernambuco, Recife, Brazil \\ ${ }^{2}$ Oceanographic Institute, Universityof São Paulo, São Paulo, Brazil \\ ${ }^{3}$ Departament of Environmental Analysis, Regional Center Nuclear Science of Northeast, Rio de Janeiro, Brazil \\ Email: *diego.a.xavier@gmail.com
}

How to cite this paper: Barcellos, R.L., Figueira, R.C.L., França. E.J., Schettini, C.A. and de Arruda Xavier, D. (2017) Changes of Estuarine Sedimentation Patterns by Urban Expansion: The Case of Middle Capibaribe Estuary, Northeastern Brazil. International Journal of Geosciences, 8, 514-535.

https://doi.org/10.4236/ijg.2017.84027

Received: November 21, 2016

Accepted: April 18, 2017

Published: April 21, 2017

Copyright $\odot 2017$ by authors and Scientific Research Publishing Inc. This work is licensed under the Creative Commons Attribution International License (CC BY 4.0).

http://creativecommons.org/licenses/by/4.0/

(c) (i) Open Access

\begin{abstract}
The aim of this study is to describe the sedimentary evolution occurred during the last 200-years in the middle Capibaribe Estuary by mean of the sedimentary analysis (magnetic susceptibility, grain size, calcium carbonate, total organic matter-TOM) and geochemical parameters (sedimentation rates, heavy metal concentrations, enrichment and contamination factor) along a core. The core recorded four units and the measured sedimentation rate was $0.52 \mathrm{~cm}$ $\mathrm{cm} \cdot \mathrm{y}^{-1}$. The first unit, dating before 1812, showed environmental characteristics of mangrove with predominance of fine sediments, high total organic matter percentages and heavy metal concentrations probably from natural sources. The second unit, from 1812 to 1937 , showed a slight increase in sand percentages and decrease in fine fraction, TOM contents and heavy metals concentrations. These characteristics may be associated with the urban expansion processes and the presence of monoculture of sugar cane occurred in the middle Capibaribe Estuary. The third unit, from 1937 to 2004, showed the highest sand percentages of the core, characterizing a unit exclusively of sand with low fine fractions percentages, total organic matter contents and heavy metals concentrations. This unit represented the intensification of the urban processes expansion of Recife City. The fourth unit showed increases in fine fraction sedimentation, TOM contents and heavy metals concentrations. This new change in sedimentation probably is consequence of rebirth of marginal estuarine banks by mangrove vegetation, due to environmental projects carried out by Recife Prefecture in the early 2000's. It was not possible to register the anthropic contamination to middle estuary area probably due to the Barreiras Formation influences in the metal concentration records, masking the anthropic contamination inputs in estuarine region. Although, lead and arsenic showing an enrichment level indicating anthropic contamination.
\end{abstract}




\section{Keywords}

Sedimentary Evolution, Grain Size, Heavy Metals, Sedimentation Rate

\section{Introduction}

The estuaries are transition areas between continental and ocean interface and they are important environments in comprehension of the coastal areas development and prevision of future evolving tendencies [1]. The sediments deposits are important because it could preserve the history of sedimentation in coastal environments [2]. Estuarine sedimentation is a consequence of many conditions, such as the sediment source that may be from the river or marine origin [3] [4] [5]. The estuarine regions show a rich fauna and flora and these are important sources of natural resources, and around these estuarine areas located are, in general, in larger cities and industrial complexes [1].

Historically, the coastal areas are attractive to human settlements, and these form huge metropolises, that grew in disorderly way [6]. The urban and industrial development adjacent to estuarine areas may cause environmental imbalance, changing the water column chemical proprieties, sedimentation patterns, mangrove deforestation and typical forest areas, landfill of flood areas to urban expansion, building of dams, contamination of heavy metals and others [7]. The studies with sedimentary columns are used to comprehension the environmental evolution in coastal areas. These sedimentary cores may provide historical records of sedimentation patterns in coastal systems, indicating the natural baselines and changes caused by anthropic modifications during the time [8] [9].

Some parameters are employed to understand the environmental evolution such as sedimentological parameters as grain size, organic matter and calcium carbonate contents in coastal environments, that provide important information for paleoenvironmental reconstructions and may register the historical of the local and regional climatic changes [10]. Variations in magnetic susceptibility have been used for detecting anthropogenic pollution caused by power plants, metallurgical dusts, fly-ashes and urban airborne particulates [11] [12] [13] and heavy metal concentration is employing to identify natural or anthropic sources and contamination levels [14]-[19]. Finally, the use of radionuclides in coastal environments as sediment tracers offers considerable potential for determining sediment sources and sedimentation rates in drainage basins [20].

The sedimentary characteristics in cores may be associated with the development of the urban processes. Anthropic changes around the river, estuary or beach are responsible for a natural imbalance of the coastal systems as well as the interference in transport of sediments and organism cycles [1]. The anthropic induced changes occur in Capibaribe Estuary $\left(8^{\circ} \mathrm{S} / 35^{\circ} \mathrm{W}\right)$ since the start of colonization processes as such as coastline modification, dredging and landfill activities [21]. Currently, this estuary is being polluted by different sources as well as fish and shrimp farming areas, discharge of industrial and domestic wastes and 
sewage [22] [23]. In this way, the aim of this study is to describe the sedimentary evolution occurred in the middle Capibaribe Estuary by mean of the sedimentary analysis and geochemical parameters along a sedimentary core, associating with the anthropic change occurred in the estuarine system and infer the background metal values.

\section{Material and Methods}

\subsection{Study Area}

The Capibaribe Estuary is located in Recife City $\left(8^{\circ} \mathrm{S} / 35^{\circ} \mathrm{W}\right)$, Pernambuco State (Northeastern Brazil). It is formed by the Capibaribe, Tejipió/Jiquiá, Jordão, Pina and Beberibe rivers. The Capibaribe Estuary has an important ecological function, serving as a reproduction area for mammals, birds, fishes and other organisms and also is the economic and social pole for the Recife Metropolitan Region (RMR) [22] (Figure 1).

The Capibaribe River present $250 \mathrm{~km}$ of extension, from its source in Jararacá mountain chain to its mouth, draining 43 municipalities [24] [25], with a drai-
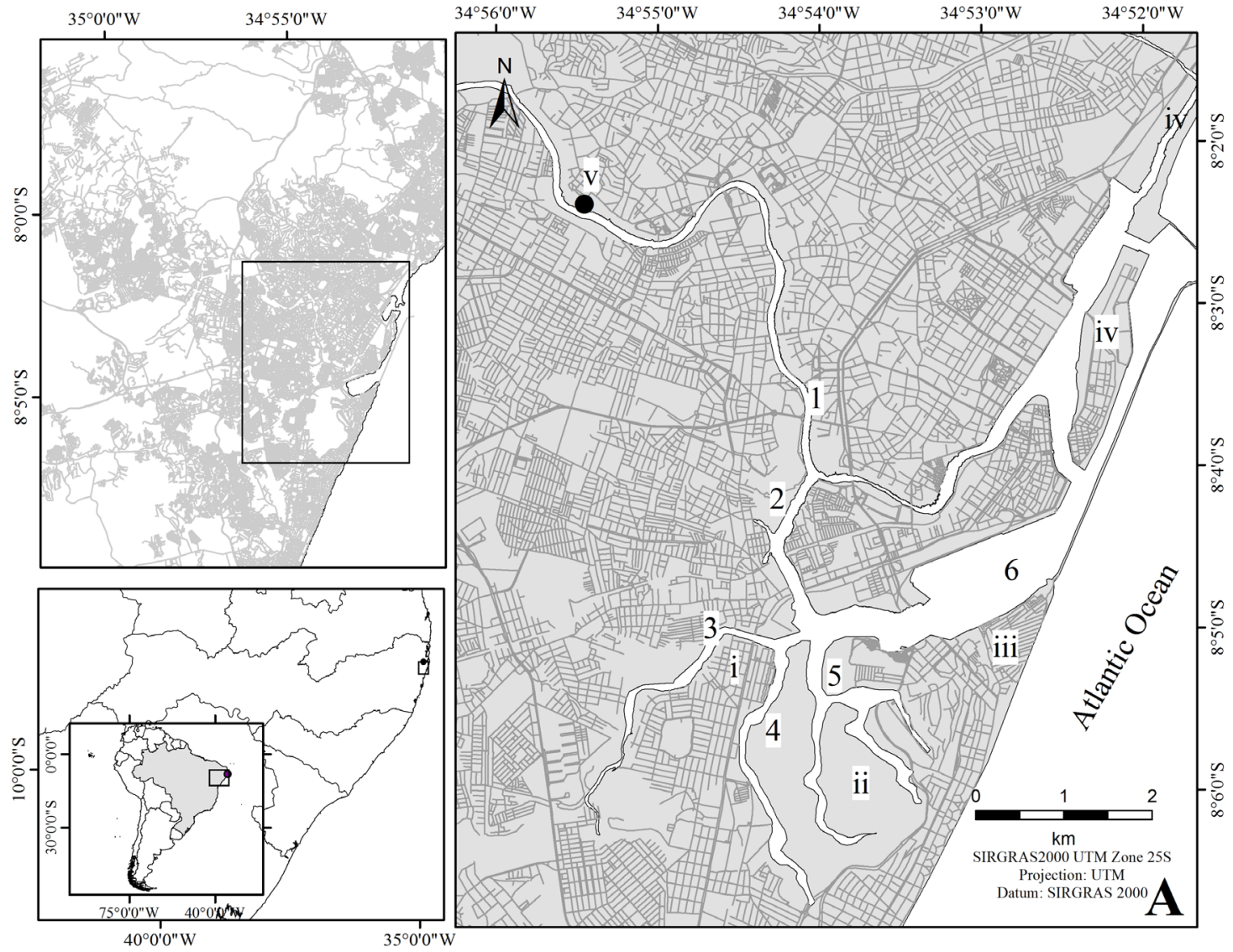

1 - Capibaribe River; 2 - Capibaribe River Bayou; 3 - Tejipió River; 4 - Jordão River; 5 - Pina River; 6 - Pina Basin. i - God Island; ii - Mangrove Park; iii - Brasília Teimosa Neighborhood; iv - Recife Port;

\section{Legend}

$$
\text { v - Poço da Panela Neighborhood }
$$

- Core Streets

Figure 1. Location map of the Capibaribe Estuary and the sedimentary core. 
nage basin of approximately $7.700 \mathrm{~km}^{2}$. The river flow on crystalline rocks, and the tertiary and quaternary sediments being drained only in the Capibaribe River lower sector. Tertiary sediments are composed by fluvial sandy deposits, intercalated with muddy sediments. Quaternary sediments form the coastal plain, corresponding to estuarine and shallow marine sediments; fluvial sediments are presents along river margins [26]. The estuary is shallow ( $<10 \mathrm{~m}$ depth).

The climate of the RMR is characterized as humid and warm tropical, As' type according to Köppen classification, with higher rainfall periods between March and August and dry periods between September and February. The average rainfall is of $2200 \mathrm{~mm} \cdot \mathrm{y}^{-1}$ and air annual temperature average of $25.2^{\circ} \mathrm{C}$ [26].

The RMR houses 3.7 millions of inhabitants, being approximately 1.5 million in Recife City and, from this number, about 218,000 inhabitants living in the middle Capibaribe Estuary. Recife City has a density population of about 7000 inhabitants $/ \mathrm{km}^{2}$ [27]. The surrounding margins of the Capibaribe River present small and degraded mangroves and the Pina Basin houses an extensive mangrove area, with approximately $20 \mathrm{~km}^{2}$, called Mangrove Park with registered Rizhophora mangle, Laguncularia racemosa, Avicennia germinans e Avicennia schaueriana specimens. Despite its environmental importance, the Mangrove Park is being affected by real estate pressure, pollution and disorderly occupation [23]. This collection of characteristics define the goal of the present research, study the estuarine sedimentary evolution in a densely urbanized tropical area.

According to [24] and [28] the grain size of surface sediments varies from silt to gravelly sand, with a prevalence of fine sediments and sands for all Capibaribe Estuarine System. However, in the middle estuary the authors observed a little change in type of sedimentation with fine fraction predominance. Concerning temporal variations, there is a slight tendency of increasing clays during periods of higher rainfall [28].

\subsection{Methods}

A $178-\mathrm{cm}$ deep core was collected in $27^{\text {th }}$ November 2012, with the aid of a push-core operated by a scuba diving at the coordinates of $8^{\circ} 02^{\prime} 22.56$ "S and $34^{\circ} 55^{\prime} 27.12 \mathrm{~W}, 0.5 \mathrm{~m}$ of water column in a marginal bank. After the core recovery, it was analyzed for magnetic susceptibility in a Bartington MS2C meter. The measurements were made with a $0.1 \times 10^{-5}$ S.I. resolution and readings were taken at $2 \mathrm{~cm}$ intervals [13]. After that, he core was opened, described and continuously sub-sampled at intervals of $2 \mathrm{~cm}$. Samples were dried at $50^{\circ} \mathrm{C}$ in order to be analyzed for grain size, organic matter and calcium carbonate contents, metal concentrations and determination of sedimentation rates by ${ }^{210} \mathrm{~Pb}_{\mathrm{xs}}$ activity.

Total calcium carbonate and organic matter were determined according the methods proposed by [29]. The calcium carbonate was determined by weight difference of the sediment prior and after addition of hydrochloric acid (10\%). The total organic matter was determined also by weight difference prior and after addition of hydrogen peroxide (10\%), until total reaction. Both results are presented as percentages of the bulk sample. 
Grain size was determined in a Malvern Mastersizer 2000 laser sedimentometer, after calcium carbonate and organic matter removal of samples. Results allowed the determination of the grain size statistical parameters proposed by [30] and sediment classification by [31], by mean of the Sysgran 3.0 software [32].

The sedimentation rate result followed radionuclide ${ }^{210} \mathrm{~Pb}$ determination method described by Saito et al. (2001), that is based in ${ }^{210} \mathrm{~Pb}$ half-live decay $\left(\mathrm{t}_{1 / 2}=\right.$ 22.3 years) [34]. The sedimentation rate value was calculated by CIC model (Constant Initial Concentration) [35]. A maximum time span of 200 years was considered for the age determinations [36].

The metal concentrations were obtained by energy dispersive X-ray fluorescence (EDXRF). The method is a multi-elementary analysis that it is based in exciting of chemical element atoms of samples; the values of element concentrations were calculated according dispersion, detection and mensuration these $\mathrm{X}$-rays [37]. For metal analysis in sedimentary samples were used proximally $1 \mathrm{~g}$ of sediment in polyethylene tubes and were sealed with polyethylene film for EDXRF analysis. The results were measured in equipment ED-720 (Shimadzu) with rhodium X-ray tube and $\mathrm{Si}(\mathrm{Li})$ detector for characteristic element quantifications. For methodology certification was utilization two reference samples of National Institute of Standard and Technology (NIST) and of International Energy Atomic Agency (IAEA), SRM2709 San Joaquin Soil and IAEA-Soil7 respectively (Table 1 ). These soil reference were analyzed together the environment sediments and at time of 300 seconds. $\mathrm{Cu}, \mathrm{Co}, \mathrm{Fe}, \mathrm{Ga}, \mathrm{La}, \mathrm{Mn}, \mathrm{Ni}, \mathrm{Pb}, \mathrm{Rb}$, $\mathrm{Sr}, \mathrm{Ti}, \mathrm{V}$ and $\mathrm{Zn}$ elements were used Mo filter and voltage adjusted at $50 \mathrm{kV}$ and $\mathrm{Al}, \mathrm{Ca}, \mathrm{K}$, and Si elements were measured with $\mathrm{Al}$ filter and voltage of $15 \mathrm{kV}$. The values are obtained and certified for the chemical elements and its respective expanded analytical uncertainties (95\% of confidence) for energy dispersive $\mathrm{X}$-ray fluorescence (EDXRF).

To identify the anomalies and evolution of the heavy concentrations, geochemistry standardizations by conservative element were used as tool, to evaluate the level of the anthropogenic contamination [38] [39]. There are two approaches to normalization of metals in sediment, the granulometric and geochemical methods [40]. The geochemical normalization is necessary standardized with alithogenic conservative element [41] [42]. Usually, Aluminum is used as lithogenic conservative element because it is a major constituent of fine-grained alumiosilicates [40] and its concentration is generally not influenced by anthropogenic sources [41] [43].

There are some types of geochemical normalization such as Al-normalized, enrichment factor, geochemical index and contamination factor. In this study will be performed enrichment factor (EF) and contamination factor (CF), and the indexes are based in the trace element concentration in base core, the Earth's background or the metal analysis reference value.

According to [44], the enrichment factor (EF) is defined as follows Equation (1):

$$
\mathrm{EF}=(\mathrm{C} / \mathrm{Al})_{\text {sample }} /(\mathrm{C} / \mathrm{Al})_{\text {background }}
$$


Table 1. Information Value (I.V) and Confidence Interval (C.I) for reference samples SRM 2709 and IAEA Soil $7\left(\mathrm{mg} \cdot \mathrm{kg}^{-1}\right)$.

\begin{tabular}{|c|c|c|c|c|}
\hline \multirow[b]{2}{*}{ Element } & \multicolumn{2}{|c|}{ SRM 2709} & \multicolumn{2}{|c|}{ IAEA Soil 7} \\
\hline & I.V & C.I & I.V & C.I \\
\hline $\mathrm{Al}$ & $2.6^{*}$ & $2.0-3.1^{*}$ & 47,000 & $44,000-5100$ \\
\hline As & $<20$ & - & 13.4 & $12.5-14.5$ \\
\hline $\mathrm{Ba}$ & 398 & $392-400$ & 159 & $131-196$ \\
\hline $\mathrm{Br}$ & - & - & 7 & $3-10$ \\
\hline $\mathrm{Ca}$ & $1.5^{\star}$ & $1.4-1.7^{\star}$ & 163,000 & $157,000-174,000$ \\
\hline Co & 12 & $10-15$ & 1.3 & $8.4-10.1$ \\
\hline $\mathrm{Cu}$ & 32 & $26-40$ & 11 & $9-13$ \\
\hline $\mathrm{Fe}$ & $3.0^{*}$ & $2.5-3.3$ & 25,700 & $25,200-26,300$ \\
\hline $\mathrm{Ga}$ & - & - & 10 & $9-13$ \\
\hline K & $0.32^{*}$ & $0.26-0.37$ & 12,100 & $11,300-12,700$ \\
\hline $\mathrm{La}$ & - & - & 28 & $27-29$ \\
\hline $\mathrm{Mg}$ & $1.4^{\star}$ & $1.2-1.5^{\star}$ & 11,300 & $11,000-11,800$ \\
\hline $\mathrm{Mn}$ & 470 & $360-600$ & 631 & $604-650$ \\
\hline $\mathrm{Ni}$ & 78 & $65-90$ & 26 & $21-37$ \\
\hline $\mathrm{P}$ & $0.07^{*}$ & $0.05-0.07^{\star}$ & 460 & $460-462$ \\
\hline $\mathrm{Pb}$ & 13 & $12-18$ & 60 & $55-71$ \\
\hline $\mathrm{Rb}$ & - & - & 51 & $47-56$ \\
\hline $\mathrm{Si}$ & $<0.01^{*}$ & - & 180,000 & $169,000-201,000$ \\
\hline $\mathrm{Sr}$ & 101 & $100-112$ & 108 & $103-114$ \\
\hline $\mathrm{Ti}$ & $0.038^{*}$ & $0.03-0.04^{*}$ & 3000 & $2600-3700$ \\
\hline V & 62 & $51-70$ & 66 & $59-73$ \\
\hline $\mathrm{Zn}$ & 100 & $87-120$ & 104 & $101-113$ \\
\hline
\end{tabular}

${ }^{*}$ concentration values in percentages

where $\mathrm{C}_{\text {sample }}$ is the trace element concentration in the sample, $\mathrm{C}_{\text {backgroung }}$ is the trace element concentration in base core, $\mathrm{Al}_{\text {sampe }}$ is the aluminum content in the sample, and $\mathrm{Al}_{\text {background }}$ is the aluminum content in base core. The $\mathrm{EF}$ values were interpreted as the levels of metal pollution as suggested by [45] where $\mathrm{EF}<1$ indicates no enrichment, $<3$ is minor, $3-5$ is moderate, $5-10$ is moderately severe, $10-25$ is severe, 25 - 50 is very severe and $>50$ is extremely severe.

The contamination level in sediments by metal is expressed in terms of a contamination factor (CF). According [46] theses values are calculated as follows Equation (2):

$$
\mathrm{CF}=\mathrm{C}_{\text {metal }} / \mathrm{C}_{\text {Backgroung }}
$$

where, $\mathrm{C}_{\text {metal }}$ is metal concentration in sample and $\mathrm{C}_{\text {background }}$ is the Earth's background or reference value of the metal analysis. The $\mathrm{CF}$ value is divided into four classes: $\mathrm{CF}<1$ refers to low contamination; $1 \leq \mathrm{CF}<3$ means moderate contamination; $3 \leq \mathrm{CF} \leq 6$ indicates considerable contamination and $\mathrm{CF}>6$ indicates very high contamination [47].

\section{Results}

The sedimentation rate for the core was $0.52 \mathrm{~cm} \cdot \mathrm{y}^{-1}$, and according to the sedi- 
mentary and geochemistry characteristics were recorded four units. The first unit $(106-178 \mathrm{~cm})$ refers to period before at 1812 , this unit shows mean magnetic susceptibility values of $22.5 \times 10^{-5} \mathrm{SI}$, grain size varied from fine silt to very fine sand with predominance of coarse silt, low sand percentages (average $43.6 \%$ ) and high silt and clay percentages (averages of $47.0 \%$ and $9.4 \%$, respectively). The calcium carbonate percentages and TOM contents showed higher percentages with average of $11.8 \%$ and $8.5 \%$, respectively, although the samples are siliciclastic [48]. The $\mathrm{Mn}, \mathrm{Fe}, \mathrm{Co}, \mathrm{Ni}, \mathrm{Cu}$ and $\mathrm{Ga}$ elements show low concentrations and $\mathrm{Zn}, \mathrm{Pb}, \mathrm{Ti}, \mathrm{V}, \mathrm{Mg}$ and $\mathrm{Al}$ high contents, when compared with background values of [49] (Table 2).

The Unit $2(42-106 \mathrm{~cm})$, refers to the period from 1812 to 1937, shows average MS values are $23.0 \times 10^{-5}$ SI. This interval is represented by sandy characteristics, grain size varying from medium silt to very fine sand with very fine sand predominance. This unit registered a slightly increase in sand percentages (average of 61.6\%) and light decrease in silt and clay percentages (averages of 31.7\% and $6.8 \%$, respectively) when compared with the Unit 1 . The calcium carbonate percentages and TOM contents show averages of $10.7 \%$ and $8.7 \%$, respectively.

Table 2. Average concentrations of parameters analyzed to core of middle Capibaribe Estuary. SM: Susceptibility Magnetic; $\mathrm{CaCO}_{3}$ : Calcium Carbonate; TOM: Total Organic Matter.

\begin{tabular}{|c|c|c|c|c|c|}
\hline & Unit 1 & Unit 2 & Unit 3 & Unit 4 & $\begin{array}{c}\text { Turekian \& Wede- } \\
\text { pohl (1961) [49] }\end{array}$ \\
\hline $\mathrm{MS}^{\star \star}$ & $22.5 \pm 4.6$ & $23.0 \pm 3.0$ & $28.5 \pm 3.6$ & $12.5 \pm 2.5$ & - \\
\hline $\mathrm{CaCO}_{3}{ }^{*}$ & $11.8 \pm 3.7$ & $10.7 \pm 2.4$ & $6.9 \pm 2.9$ & $9.9 \pm 2.1$ & - \\
\hline $\mathrm{TOM}^{*}$ & $8.5 \pm 3.2$ & $8.7 \pm 2.4$ & $6.6 \pm 2.9$ & $7.1 \pm 0.6$ & - \\
\hline Sand $^{\star}$ & $43.6 \pm 15.6$ & $61.6 \pm 10.4$ & $86.5 \pm 6.8$ & $48.1 \pm 3.8$ & - \\
\hline Silt* & $47.0 \pm 12.5$ & $31.7 \pm 8.4$ & $11.4 \pm 5.8$ & $45.4 \pm 4.2$ & - \\
\hline Clay* & $9.4 \pm 3.7$ & $6.8 \pm 2.4$ & $2.1 \pm 1.0$ & $6.5 \pm 0.3$ & - \\
\hline $\mathrm{Mn}$ & $438.4 \pm 100.3$ & $349.4 \pm 35.8$ & $320.7 \pm 50.9$ & $313.7 \pm 18.0$ & 850 \\
\hline $\mathrm{Fe}^{*}$ & $3.9 \pm 0.7$ & $3.8 \pm 0.5$ & $2.8 \pm 0.6$ & $3.1 \pm 0.4$ & 4.7 \\
\hline Co & $15.8 \pm 2.9$ & $16.7 \pm 2.8$ & $11.7 \pm 2.4$ & $13.1 \pm 2.3$ & 19 \\
\hline $\mathrm{Ni}$ & $28.9 \pm 3.6$ & $23.1 \pm 2.4$ & $19.6 \pm 2.6$ & $277.2 \pm 260.1$ & 68 \\
\hline $\mathrm{Cu}$ & $50.8 \pm 9.1$ & $29.9 \pm 14.2$ & $22.9 \pm 9.8$ & $36.8 \pm 22.0$ & 45 \\
\hline $\mathrm{Zn}$ & $157.0 \pm 33.0$ & $156.9 \pm 27.2$ & $116.7 \pm 28.6$ & $138.7 \pm 22.2$ & 95 \\
\hline $\mathrm{Ga}$ & $10.9 \pm 1.0$ & $10.8 \pm 0.6$ & $9.5 \pm 0.7$ & $9.7 \pm 0.4$ & 19 \\
\hline As & $288.4 \pm 74.4$ & $224.6 \pm 33.4$ & $118.8 \pm 44.5$ & $120.6 \pm 15.3$ & 13 \\
\hline $\mathrm{Pb}$ & $90.1 \pm 18.1$ & $74.5 \pm 9.0$ & $49.2 \pm 10.7$ & $48.9 \pm 2.3$ & 20 \\
\hline $\mathrm{Ti}$ & $4685.0 \pm 398.7$ & $4770.7 \pm 305.6$ & $4264.3 \pm 326.2$ & $4257.4 \pm 176.3$ & 4600 \\
\hline V & $290.4 \pm 24.7$ & $298.1 \pm 24.0$ & $267.4 \pm 29.3$ & $255.0 \pm 21.6$ & 130 \\
\hline $\mathrm{Mg}^{*}$ & $0.7 \pm 1.1$ & $0.6 \pm 0.1$ & $0.5 \pm 0.1$ & $0.5 \pm 0.1$ & 1.5 \\
\hline $\mathrm{Al}^{*}$ & $10.8 \pm 1.5$ & $11.1 \pm 0.6$ & $8.9 \pm 1.3$ & $8.8 \pm 0.1$ & 8.0 \\
\hline
\end{tabular}

${ }^{*}$ values in percentage; other elements in $\mathrm{mg} \cdot \mathrm{kg}^{-1}$; ${ }^{* *} 10^{-5}$ S.I. 
The Unit 2 showed the same patterns in heavy metal concentration of the Unit 1 , when compared with background values of [49] (see Table 2).

The Unit $3(4-42 \mathrm{~cm})$, refers to the period from 1937 to 2004, shows average MS values of $28.5 \times 10^{-5} \mathrm{SI}$. This interval presents sandy characteristics, however is slightly different from Unit 2, mainly due to the mean diameter. This unit showed grain size varying from very fine sand to medium sand with predominance of fine sand. Sand, silt and clay percentages records averages of $86.5 \%$, $11.4 \%$ and $2.1 \%$, respectively. The calcium carbonate percentages and TOM contents show averages of $6.9 \%$ and $6.6 \%$ respectively. The heavy metal concentration showed lower levels, when compared with Units 1 and 2. However, the Zinc, Arsenic and Aluminum concentrations show indexes above the background values from [49] (see Table 2).

Lastly, the Unit $4(0-4 \mathrm{~cm})$, refers to the period from 2004 to 2012 , showing the lowest averages of MS values of units with $12.5 \times 10^{-5} \mathrm{SI}$. This unit presents a silty character, with grain size classified as coarse silt. This unit shows sand, silt and clay percentages averages of $48 \%, 45 \%$ and $6 \%$, respectively. The calcium carbonate percentages and TOM contents record averages of $10 \%$ and $7 \%$, respectively. This unit show a lightly decrease in heavy metal concentration when compared with Unit 1, showing concentrations below of [49] (see Table 2).

The vertical variation records MS, TOM, calcium carbonate, sand, silt and clay percentage and heavy metal concentration peaks along of core are represented by the Figure 2 and Figure 3.

The enrichment factor (EF) [44] shows no enrichment values to $\mathrm{Mn}, \mathrm{Fe}, \mathrm{Co}$, $\mathrm{Ni}, \mathrm{Cu}, \mathrm{Ga}, \mathrm{Ti}, \mathrm{Mg}$ with $\mathrm{EF}<1$. $\mathrm{Zn}, \mathrm{Pb}$ and $\mathrm{V}$ show values of lower enrichment with $\mathrm{EF}<3$, and As shows a moderate to moderately severe enrichment factor values, with higher enrichment $(5<\mathrm{EF}<25)$ (Figure 4 ).

The contamination factor [46] values show lower contamination to $\mathrm{Mn}, \mathrm{Fe}$, $\mathrm{Co}, \mathrm{Cu}, \mathrm{Ga}$ with $\mathrm{CF}<1$. Ni, $\mathrm{Zn}, \mathrm{Ti}, \mathrm{V}$ and $\mathrm{Al}$ show moderately contamination with $1 \leq \mathrm{CF} \leq 3$. The $\mathrm{Pb}$ and As show considerable contamination $(3 \leq \mathrm{CF} \leq 6)$ and higher one $(\mathrm{CF}>6)$, respectively (Figure 5 ).

\section{Discussion}

The sedimentary characteristics in cores may be associated with the development of the urban processes. Anthropic changes around the river, estuary or beach are responsible for a natural imbalance of the coastal systems as well as the interference in transport of sediments and organism cycles [1]. The units registered in the core demonstrate influences of different events in sedimentation patterns to middle Capibaribe Estuary.

The Unit 1 recorded the finer sedimentation, TOM and metals, with some peaks of sandy sedimentation at 130,134 and $142 \mathrm{~cm}$ of the core-deep. This unit shows probably the estuarine mangrove environment characteristics, with variation in the hydrodynamic energy represented by the sand peaks. Other evidence that corresponds the mangrove environment is associated with high TOM contents (from $2.1 \%$ to $15.6 \%$ ) [50] [51]. Calcium carbonate peaks registered in this 


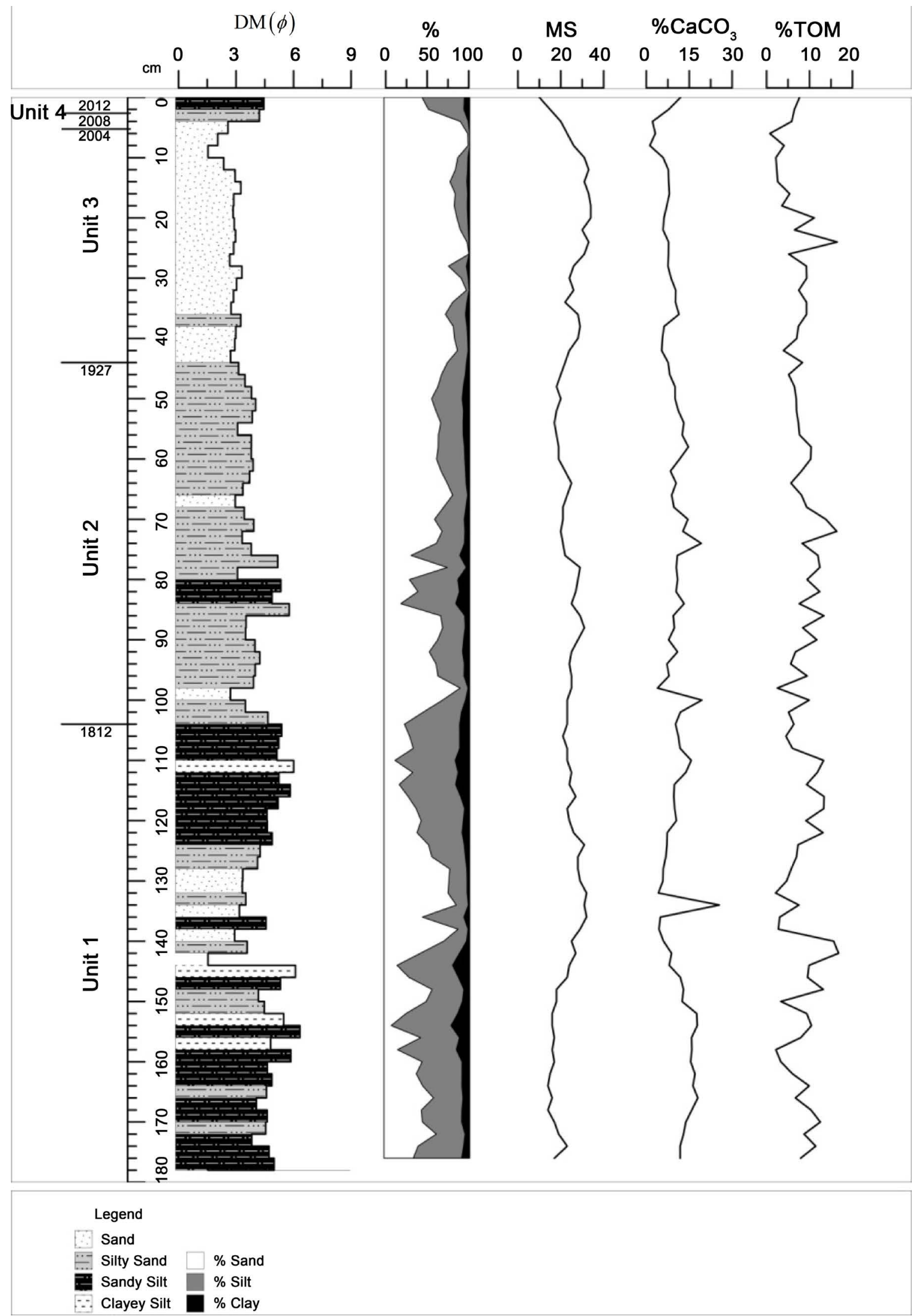

Figure 2. Vertical variation [31] facies diagram classification, mean diameter, magnetic susceptibility, calcium carbonate and total organic matter contents. 


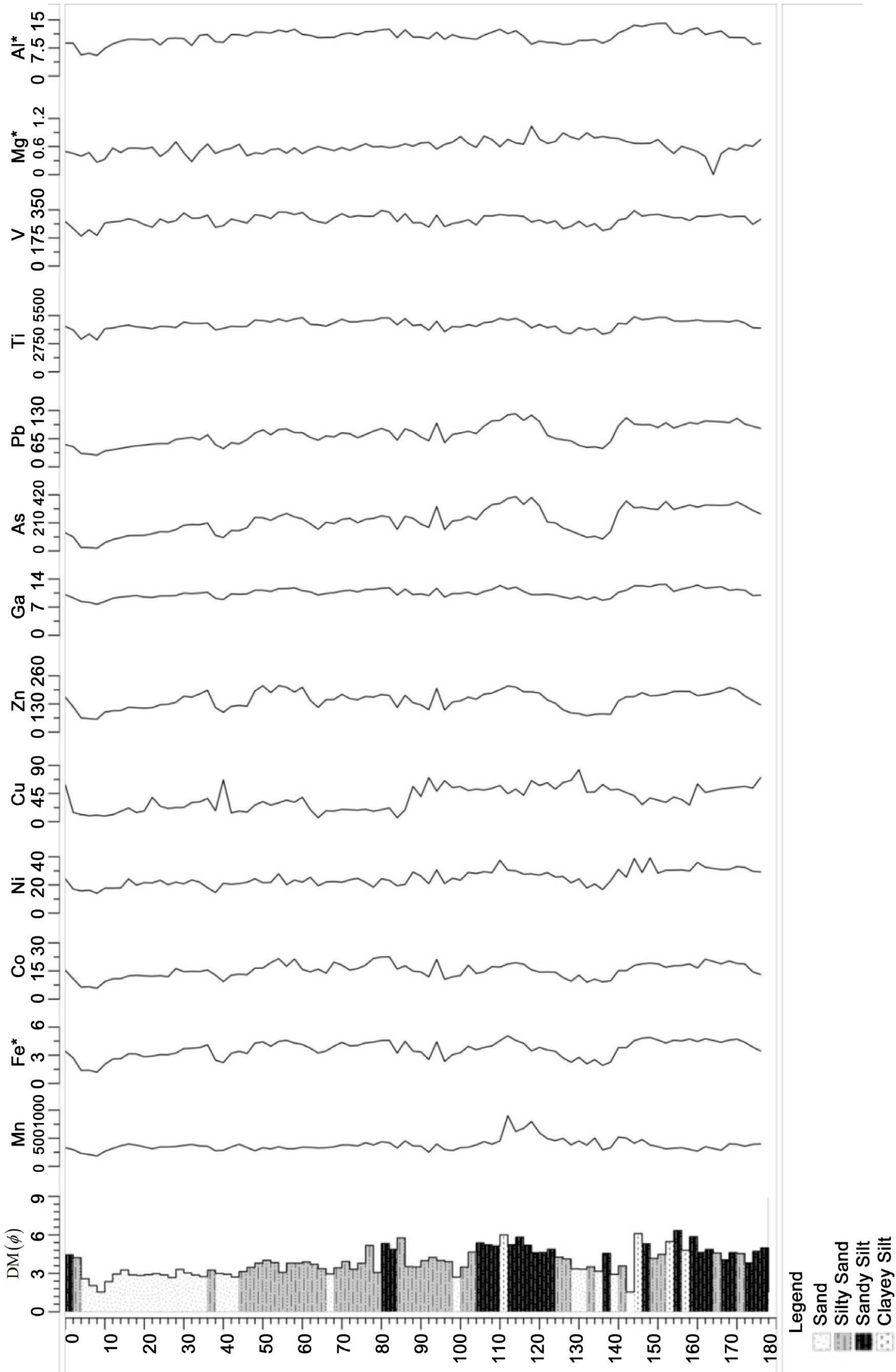

Figure 3. Vertical variation of metal concentrations in sedimentary core. 


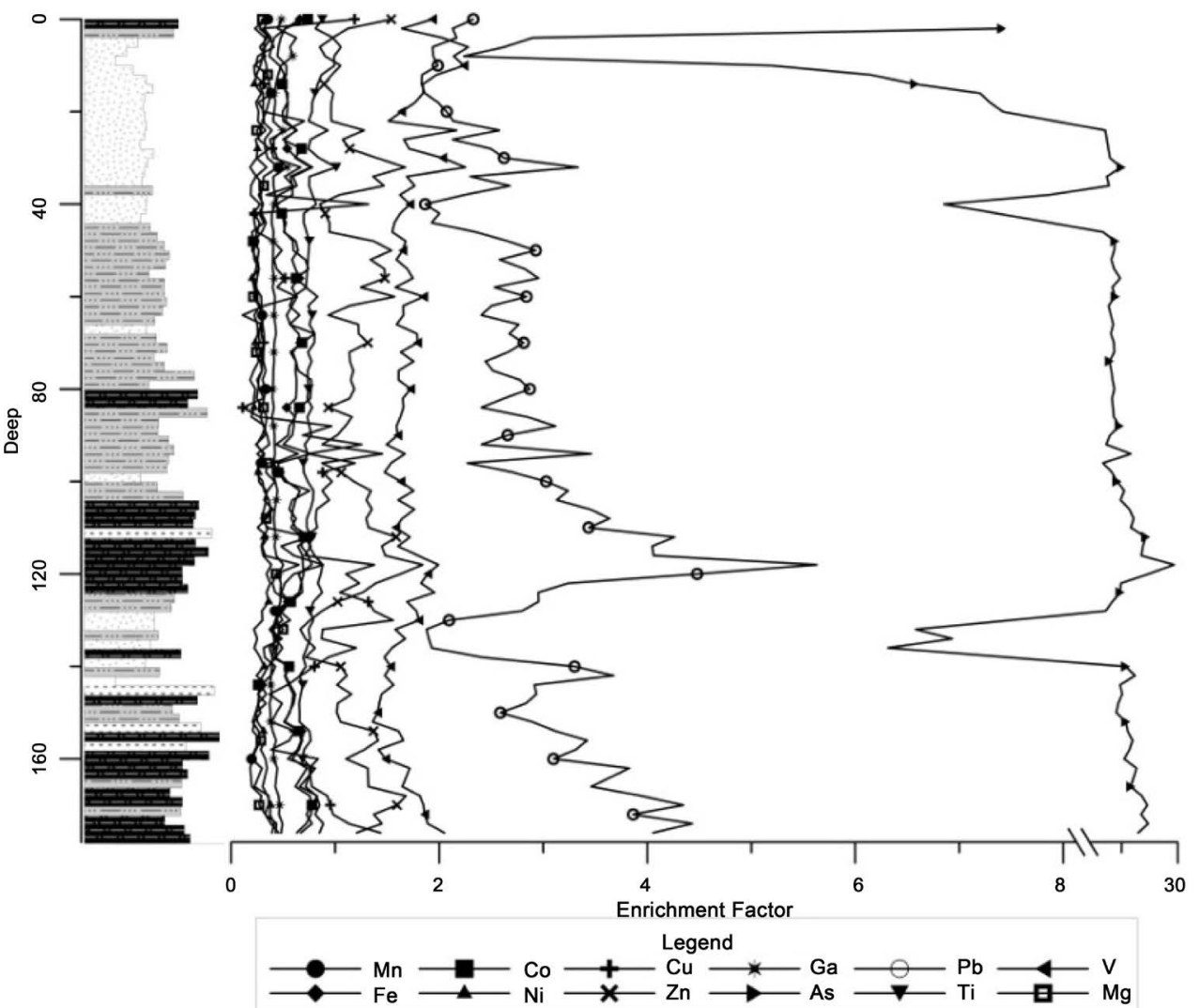

Figure 4. Vertical variation of enrichment factor (EF) of the sedimentary core.

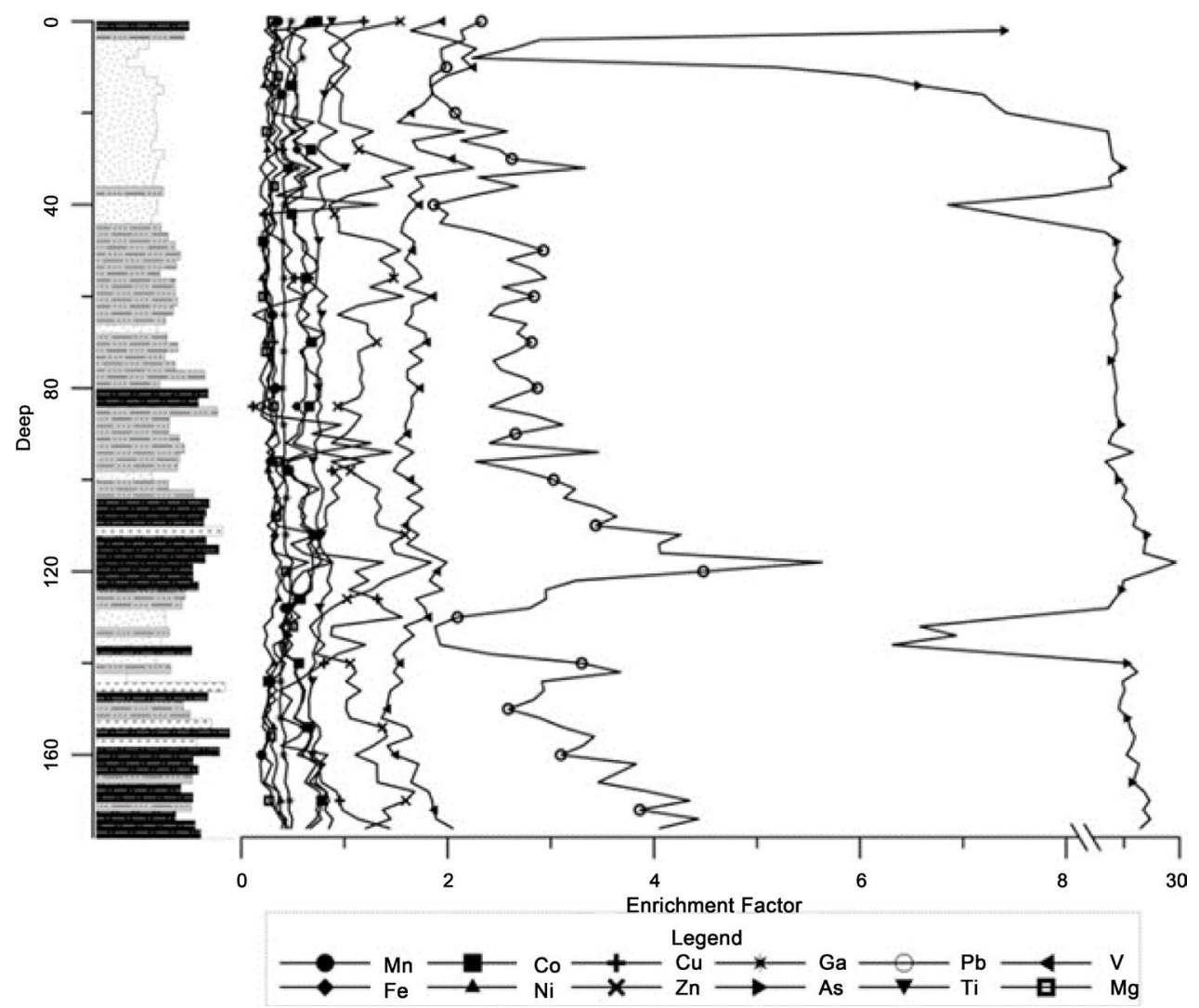

Figure 5. Vertical variation of contaminantion factor (CF) of the sedimentary core. 
unit may be associated with high productivity of organisms with carbonate shells present in mangroves [52] [53]. Probably, the metal concentration values are from natural sources, associated with the local/regional inputs from the Barreiras Formation [54] [55] [56] [57].

According to [58], the Poço da Panela, the neighborhood area located in the middle estuary, was a small village founded in 1758 and its accesses to village were made in tracks inside the Atlantic forest. The urban development in the Poço da Panela started 1812, with open of streets and hills. In this time, take river bath was the medical recommendation to cure of diseases, and the Poço da Panela was chosen as a local exclusive for high society of Recife.

Surrounding the middle Capibaribe Estuary, there were big farms of sugar cane plantation as Casa Forte and Madalena mills. The monoculture of sugar cane was the main economy product of the colonial Pernambuco province [59] [60]. Because of medical recommendation, the urbanization processes of Poço da Panela was intensified by the building of summer houses at margins of Capibaribe River, changing urban space in this estuary area as registered in the Unit 2.

The increasing in sand percentages and decreasing in silt and clay contents is associated in Unit 2 probably are related with mangrove deforestation specifically in the margins of Capibaribe River caused by the urban expansion of Recife City westward. Furthermore, mangrove deforestation associated to the sugar cane mills installations also may have been the greater contributor in the increase of sand percentage. The monoculture of cane sugar was responsible by to deforest the majority part of Atlantic Forest located around of Capibarbe estuary, facilitating the erosion and increasing the sediment transport from continental and margins to the river causing silting processes [61] [62]. The urban processes intensification occurred during $19^{\text {th }}$ and $20^{\text {th }}$ centuries, mainly with arrival of Englishman and German, that were employees of the utility companies and preferred to live in this area [58] [59] (Figure 6).

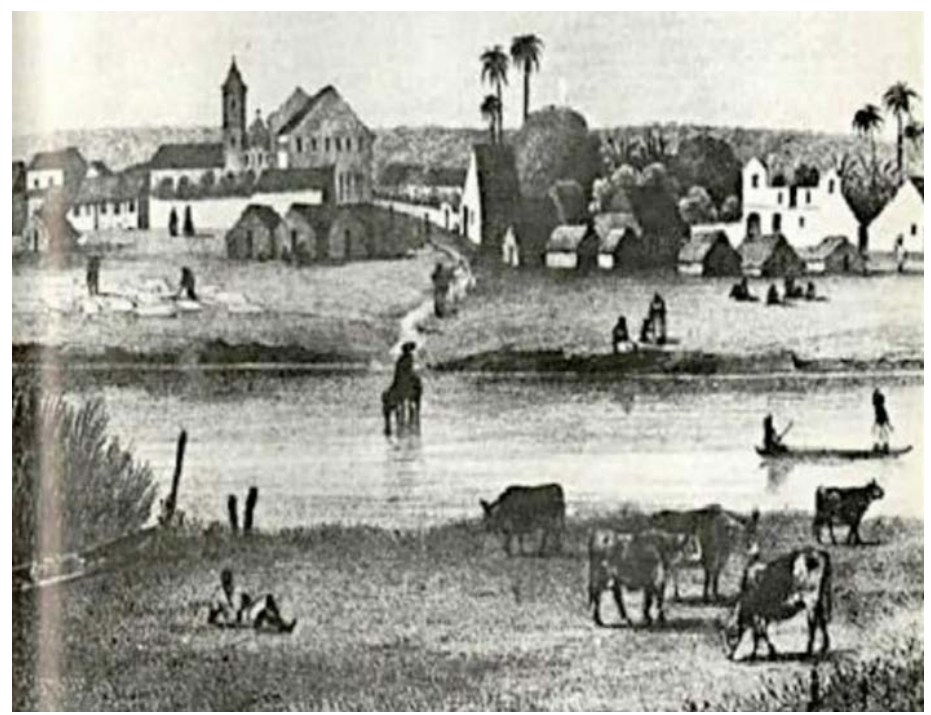

Figure 6. Poço da Panela Village in 1847. The Capibaribe River margins were without mangrove vegetation (Unknown Author). 
In this unit (Unit 2) shows a decrease in averages of metal concentrations when compared with Unit 1 (see Table 2). Probably this is associated with greater the sand percentages in sedimentation and decrease in the clay percentages [54] [63]. [64] affirms that clays adsorbs four times more organic matter and metals from sands, and two times more from silts. [56] also affirmed that increases in the metal concentrations are associated with high depositions of finer sediments or inputs in the metal concentrations of natural and/or anthropic sources. How Recife City shows a small industrialization processes, this peaks observed in Unit 2 are possibly inputs of natural material from Barreiras Sedimentary formation present around of all estuarine area [21] [57].

The Unit 3 is essentially sandy and probably records the intensification of urban development of middle Capibaribe Estuary in mid- $19^{\text {th }}$ century. The increase of the buildings together with the population growth were responsible by the cause of the most changes in around the middle estuary, such as landfill of flood areas, the intensification of mangrove deforestation and canalization of some rivers that compound the hydrographic basin of Capibaribe River estuarine portion [21] [58]. During the $19^{\text {th }}$ century, the urbanization turns its back to the river, and thus, the Capibaribe River passed to be the city's dumping area, receiving all industries and domestics wastes [65] [66]. During this period the Recife City did not show a development of industrial plants. Therefore, the decrease in metal concentrations recorded in Unit 3 may be associated the greater sedimentation of sand (averages of $86.5 \%$ ) and decrease in silt and clay percentages and TOM (11.4\%, $2.1 \%$ and $6.6 \%$, respectively).

Other important fact is that the Recife's prefecture made a reforestation project of mangrove vegetation in Capibaribe River margins at the mid-90s and in the early $20^{\text {th }}$ century. In this period was registered an increase in mangrove vegetation of approximately $14.2 \mathrm{~km}^{2}$ (analyzing the period from 1999 to 2006) and $12.6 \mathrm{~km}^{2}$ (analyzing period from 1997 to 2007) according [67] [68] to middle Capibaribe Estuary, respectively.

This project of Recife's prefecture showed great results well as observed by [67] [68], being observed in sedimentary core of middle estuary represented by Unit 4. This unit showed increases in silt and clay percentages (averages of $45.4 \%$ and $6.5 \%$, respectively) when compared with unit 3, and a layer highly sandy (averages of $11.4 \%$ and $2.1 \%$, respectively). In Unit 4 , the increases in fine sedimentation are associated possibly with progradation of the mangrove areas located in margins of Capibaribe Estuary as well as the TOM contents increasing and metal concentrations (see Figure 2).

According to the graphic of enrichment factor (EF) and contamination factor (CF), the majority of metals do not show high levels of enrichment and contamination (Figure 5 and Figure 6). Only $\mathrm{Pb}$ and As showed enrichment and contamination levels. According [38] [45] [69], rich rocks in heavy metals in its composition may mask the enrichment and contamination level. In the case of Capibaribe Estuary, the Barreiras Formation is a greater contributor of metal source [57]. 
[70] [71] [72] affirmed that the strong correlations between metals with Fe and/or $\mathrm{Al}$ possibly represent same metal source. In case of middle estuary, the metal concentrations to estuarine system may be from Barreiras Formation such as main source. The anthropic sources also may be registered in this metal concentrations, however this anthropic contribution do not show clearly along of sedimentary core. The correlation values between the metals demonstrated this same metal source for middle Capibaribe Estuary, confirming the Barreiras Formation influences in sedimentation (Table 3).

[73] affirm that soils and rocks of Pernambuco State are composed by high concentrations of Arsenic in their composition. The strong correlations between As and $\mathrm{Al}(\mathrm{r}>0.7)$ indicate increases of natural metal concentrations, derived of erosion or lixiviation of Tertiary rocks, of the Barreiras Formation, that compounds the low lands of the drainage system.

Correlations between metals and calcium carbonate implies that it could be related to the origin of carbonate that it diagenetic. These formations occur in zones of shallow sub-bottom layers, presence of metabolizable organic matter, oxide and hydroxide (principally iron and manganese), oxygen and sulfate ions concentrations dissolved in pore water [74] [75] associated to the bacterial action [76]. [16] [77] [78] affirm that the carbonate diagenetic formation may oc-

Table 3. Pearson correlation values registered to all parameter analyzed to sedimentary core.

\begin{tabular}{|c|c|c|c|c|c|c|c|c|c|c|c|c|c|c|c|c|c|c|c|}
\hline & MS & $\mathrm{CaCO}_{3}$ & TOM & Sand & Silt & Clay & $\mathrm{Mn}$ & $\mathrm{Fe}$ & Co & $\mathrm{Ni}$ & $\mathrm{Cu}$ & $\mathrm{Zn}$ & $\mathrm{Ga}$ & As & $\mathrm{Pb}$ & $\mathrm{Ti}$ & $\mathrm{V}$ & $\mathrm{Mg}$ & $\mathrm{Al}$ \\
\hline SM & 1.0 & & & & & & & & & & & & & & & & & & \\
\hline $\mathrm{CaCO}_{3}$ & -0.5 & 1.0 & & & & & & & & & & & & & & & & & \\
\hline TOM & -0.1 & 0.3 & 1.0 & & & & & & & & & & & & & & & & \\
\hline Sand & 0.4 & -0.5 & -0.3 & 1.0 & & & & & & & & & & & & & & & \\
\hline Silt & -0.4 & 0.5 & 0.3 & -1.0 & 1.0 & & & & & & & & & & & & & & \\
\hline Clay & -0.4 & 0.5 & 0.2 & -0.9 & 0.9 & 1.0 & & & & & & & & & & & & & \\
\hline $\mathrm{Mn}$ & 0.1 & 0.1 & 0.5 & -0.4 & 0.4 & 0.3 & 1.0 & & & & & & & & & & & & \\
\hline $\mathrm{Fe}$ & -0.5 & 0.6 & 0.5 & -0.6 & 0.6 & 0.6 & 0.4 & 1.0 & & & & & & & & & & & \\
\hline Co & -0.4 & 0.6 & 0.4 & -0.6 & 0.5 & 0.6 & 0.3 & 0.9 & 1.0 & & & & & & & & & & \\
\hline $\mathrm{Ni}$ & -0.3 & 0.1 & 0.0 & -0.1 & 0.2 & 0.0 & 0.0 & 0.0 & 0.1 & 1.0 & & & & & & & & & \\
\hline $\mathrm{Cu}$ & -0.1 & 0.1 & 0.1 & -0.3 & 0.4 & 0.2 & 0.3 & 0.1 & 0.0 & 0.2 & 1.0 & & & & & & & & \\
\hline $\mathrm{Zn}$ & -0.6 & 0.6 & 0.4 & -0.6 & 0.5 & 0.6 & 0.4 & 0.9 & 0.8 & 0.1 & 0.1 & 1.0 & & & & & & & \\
\hline $\mathrm{Ga}$ & -0.5 & 0.6 & 0.4 & -0.6 & 0.6 & 0.6 & 0.2 & 0.9 & 0.9 & 0.0 & 0.1 & 0.9 & 1.0 & & & & & & \\
\hline As & -0.5 & 0.6 & 0.4 & -0.7 & 0.7 & 0.7 & 0.5 & 0.9 & 0.8 & 0.0 & 0.4 & 0.9 & 0.8 & 1.0 & & & & & \\
\hline $\mathrm{Pb}$ & -0.5 & 0.5 & 0.4 & -0.7 & 0.7 & 0.7 & 0.5 & 0.9 & 0.8 & 0.0 & 0.4 & 0.8 & 0.8 & 1.0 & 1.0 & & & & \\
\hline $\mathrm{Ti}$ & -0.4 & 0.6 & 0.4 & -0.5 & 0.5 & 0.6 & 0.3 & 0.9 & 0.9 & 0.0 & -0.1 & 0.8 & 0.9 & 0.7 & 0.7 & 1.0 & & & \\
\hline $\mathrm{V}$ & -0.3 & 0.5 & 0.4 & -0.4 & 0.4 & 0.5 & 0.3 & 0.9 & 0.8 & 0.0 & 0.0 & 0.8 & 0.9 & 0.7 & 0.7 & 0.9 & 1.0 & & \\
\hline $\mathrm{Mg}$ & 0.2 & 0.0 & 0.1 & -0.3 & 0.3 & 0.2 & 0.5 & 0.0 & 0.0 & -0.1 & 0.5 & 0.0 & 0.0 & 0.2 & 0.3 & -0.1 & 0.0 & 1.0 & \\
\hline $\mathrm{Al}$ & -0.4 & 0.5 & 0.3 & -0.5 & 0.4 & 0.6 & 0.1 & 0.8 & 0.8 & -0.1 & 0.0 & 0.7 & 0.9 & 0.7 & 0.7 & 0.9 & 0.8 & 0.1 & 1.0 \\
\hline
\end{tabular}

-bold values $(\mathrm{p}<0.001 ; \mathrm{n}=87)$. 
cur in any layer during sedimentation processes, depending of the available organic matter. This relation may be observed in correlation values between Iron and calcium carbonate and total organic matter $(r=0.6)$ (see Table 3).

Arsenic and Lead enrichment in Brazilian coastal environments were reported in several works as [79]-[84]. High levels of As (i.e. above the nationally thereshold of $70 \mathrm{mg} .{ }^{\mathrm{kg}-1}$ ) were found in shelf, beach and nearshore sands, lagoonal/swamp and mangrove sediments of Espírito Santo, Bahia [80] [81], Rio de Janeiro [82] and Rio Grande do Sul states [84]. A significant positive correlation between As and calcium carbonate $(r=0.6)$ could indicate that the calcareous bioclasts participate in metalloid retention and its accumulation in coastal sediments as observed by [81]. This affinity with carbonates added to the As inputs from: (a) the eroded material from continental rocks and sediments [80] local sources (Borborema Crystalline Complex and the Barreiras Group ferrous sandstones); (b) the groundwater aquifer [82]; (c) the atmospheric fallout [82], could implies in the high values observed in the studied core $\left(>120.0 \mathrm{mg} \cdot \mathrm{kg}^{-1}\right)$. Similarly as observed for the Paraíba do Sul delta region [82] and Patos Lagoon estuarine sediments [84] the Arsenicis retained mainly by iron hidroxides in upper and probably by sulfides in lower layers due to diagenetic processes. In fact the high significant correlation of As with iron $(\mathrm{r}=0.9)$ and $\mathrm{Pb}(1.0)$ reinforce the local enrichment from post depositional processes and atmospheric fallout, also indicated by the $\mathrm{Pb}$ enrichment, especially in the upper units of the core ( 1 and 2).

[85] observed finer sedimentation and TOM peaks associated with occurrence of floods registered in Recife to the lower Capibaribe Estuary. In case of middle estuary is not possible to identify finer sedimentation associated with flood registers. It is believed that the suspended sediments by rains transport is deposited mainly in the middle estuarine area, registering a prevalence of fine sedimentation.

\section{Conclusions}

The modification of urban space changed the sedimentation patterns in the middle Capibaribe Estuary. The core registered four units with different sedimentary and geochemistry characteristics. First unit (Unit 1), represent ages before 1812 year, showed mangrove environment characteristics with predominance of fine sediments, high total organic matter contents and heavy metal concentrations possibly from natural sources.

The second unit (Unit 2), from 1812 to 1937, showed a small influence of sand characteristics with slightly decreases in the fine fraction percentages, TOM contents and heavy metals concentrations. This increase in sand percentages may be associated with the beginning of urban expansion processes in the middle estuary, together with intensification of monoculture of sugar cane. These two processes were responsible by majority of the Atlantic Forest deforesting, increasing the lixiviation and the transport of sandy sediments from the margins to the river. 
Third unit (Unit 3), from 1937 to 2004, showed the highest sand percentages of the sedimentary core, characterizing an exclusive sandy unit with low fine fractions percentages, total organic matter contents and heavy metals concentrations. This unit represents the intensification of urban processes expansion of Recife City. Increases in landfills of flood areas, deforesting of mangrove areas together with intensification of building processes were the main factors that contributed in the increase of sand sedimentation in estuarine system.

The fourth unit (Unit 4) showed increases in finer sedimentation, in TOM contents and heavy metals concentrations. The environmental improvement projects for Capibaribe River, in late $20^{\text {th }}$ and early $21^{\text {st }}$ centuries, were responsible by the reforesting of mangrove marginal areas of the estuary. These projects showed great results in increase of mangrove areas and these progradations could be observed in the higher mud contents in this unit of the sedimentary core.

Although all modifications that occurred since the $18^{\text {th }}$ century, the Capibaribe River was not possible to register clearly the anthropic contamination to middle estuary area. The metal concentration records may have been also influenced by natural sources, which are rich in heavy metal concentrations and surround the estuarine area. And this way, the anthropic influences could have been masked by this geological character. Although as observed by the presented results, and in similar studies, that the enrichment of $\mathrm{As}$ and $\mathrm{Pb}$ could be directly related to these elements retention and accumulation by diagenetic processes, associated to several local sources as: the carbonate sediments, the local rocks and continental sediments, the groundwater aquifer and the atmospheric fallout.

Lastly, this research may be useful in the comparison with similar sedimentary studies in densely urban estuarine areas. As well as to subsidize the determination of local metals reference/background levels in future studies employing the data collection presented in this paper.

\section{Acknowledgements}

This research work is part of the project "SUSCEPTIBILITY AND RESILIENCE OF THE URBAN ESTUARINE SYSTEMS TO GLOBAL CLIMATIC CHANGES: Hydro-sedimentary balance; rising sea level, answers for extreme events" (FACEPE/FAPESP, Project n0079-1.08/11).

\section{References}

[1] Cunha, P.P., Pinto, J. and Dinis, J.L. (1997) Evolução da fisiografia e ocupação antrópica na área estuarina do Rio Mondego e região envolvente (Portugal centrooeste), desde 1947 Abstract: integrada no Plano Director Municipal da Figueira. Territorium, 93, 99-124. https://doi.org/10.14195/1647-7723_4_8

[2] Sanders, C.J., Santos, I.R., Silva-Filho, E.V. and Patchineelam, S.R. (2006) Mercury Flux to Estuarine Sediments, Derived from Pb-210 and Cs-137 Geochronologies (Guaratuba Bay, Brazil). Marine Pollution Bulletin, 52, 1085-1089.

[3] Friedman, G.M. and Sanders, J.E. (1978) Principles of Sedimentology. Wiley, New York. 
[4] Largier, J.L. (1993) Estuarine Fronts: How Important Are They? Estuaries, 16, 1-11. https://doi.org/10.2307/1352760

[5] Uncles, R.J. (2002) Estuarine Physical Processes Research: Some Recent Studies and Progress. Estuarine Coastal and Shelf Sciences, 55, 829-256. https://doi.org/10.1006/ecss.2002.1032

[6] Sartoretto, J.R. (2014) Histórico de atividade antrópica no Sistema Estuarino Santos e São Vicente. Msc Dissertation, University of São Paulo, São Paulo.

[7] Lacerda, L.D., Maia, L.P., Monteiro, L.H.U., Souza, G.M., Bezerra, L.J.C. and Menezes, M.O.T. (2006) Manguezais do Nordeste e mudanças ambientais. Ciência Hoje, 39, 24-49.

[8] Buckley, D.E., Smith, J.N. and Winters, G.V. (1995) Accumulation of Contaminant Metals in Marine Sediments of Halifax Harbour, Nova Scotia: Environmental Factors and Historical Trends. Applied Geochemistry, 10,175-195.

[9] Li, X.D., Wai, O.W.H., Coles, B.J., Ramsey, H. and Thornton, I. (2000) Heavy Metal Distribution in the Sediment Profiles of the Pearl River Estuary, South China. Applied Geochemistry, 15, 567-581.

[10] Meyers, P.A. (1997) Organic Geochemical Proxies of Paleoceanographic, Paleolimnologic, and Paleoclimatic Processes. Organic Geochemistry, 27, 213-250.

[11] Heller, F., Strzyszcz, Z. and Magiera, T. (1998) Magnetic Record of Industrial Pollution in Forest Soils of Upper Silesia, Poland. Journal of Geophysical Research, 103, 17767-17774. https://doi.org/10.1029/98JB01667

[12] Hofmann, V., Knab, M. and Appel, E. (1999) Magnetic Susceptibility Mapping of Roadside Pollution. Journal Geochemical Exploration, 66, 313-326.

[13] Martins, C.C., Mahiques, M.M., Bícego, M.C., Fukumoto, M.M. and Montone, R.C. (2007) Comparison between Anthropogenic Hydrocarbons and Magnetic Susceptibility in Sediment Cores from the Santos Estuary, Brazil. Marine Pollution Bulletin, 54, 240-246.

[14] Birch, G.F. and Davey, S. (1995) Accumulation of Metallic Contaminants in Surficial Sediments on a High-Energy Continental Shelf, Sydney, Australia. Science of the Total Environment, 170, 81-93.

[15] Andrews, J.E., Greenaway, A.M., Bigg, G.R., Webber, D.F., Dennis, P.F. and Guthrie, G.A. (1999) Pollution History of a Tropical Estuary Revealed by Combined Hydrodynamic Modeling and Sediment Geochemistry. Journal of Marine Systems, 18, 333-343.

[16] Yu, K.C., Tsai, L.J., Chen, S.H. and Ho, S.T. (2001) Correlation Analyses on Binding Behavior of Heavy Metals with Sediment Matrices. Water Research, 35, 2417-2428.

[17] Delgado, J., Boski, T., Nieto, J.M., Pereira, L., Moura, D., Gosmes, A., Sousa, C. and García-Tenorio, R. (2012) Sea-Level Rise and Anthropogenic Activities Recorded in the Late Pleistocene/Holocene Sedimentary Infill of the Guadiana Estuary (SW Iberia). Quaternary Science Reviews, 33, 121-141.

[18] Chitrarasu, P., Ali, A.J., Babuthangadurai, T. and Manickam, N. (2013) Studies on the Heavy Metal Analysis of Sediment at Ennore Estuary in Southeast Coast of India. Current Biotica, 7, 1-7.

[19] Chatterjee, M., Silva Filho, E.V., Sarkar, S.K., Sella, S.M., Bhattacharya, A., Satpathy, K.K., Prasad, M.V.R., Chakraborty, S. and Bhattacharya, B.D. (2007) Distribution and Possible Source of Trace Elements in the Sediment Cores of a Tropical Macrotidal Estuary and Their Ecotoxicological Significance. Environmental International, 33, 346-356.

[20] Wanderley, C.V.A., Godoy, J.M., Godoy, M.L.D.P., Rezende, C.E. and Lacerda, L.D. 
(2014) Evaluating Sedimentation Rates in the Estuary and Shelf Region of the Paraíba do Sul River, Southeastern Brazil. Journal of Brazilian Chemistry Society, 25, 50-64.

[21] Pontual, V. (2001) Tempos do Recife: Representações culturais e configurações urbanas. Revista Brasileira de História, 21, 417-434. https://doi.org/10.1590/S0102-01882001000300008

[22] Macêdo, S.J., Silva, H.K.P., Brayner, F.M.M., Duarte, M.M.M.B. and Barbosa. M.F. (2007) Heavy Metal Concentrations in Sediments of the Capibaribe River Estuary in the Metropolitan Region of Recife, Pernambuco-Brazil. WIT Transactions on Ecology and the Environment, 102, 357-365.

[23] Silva, H.K.P., Macêdo, S.J. and Bryner, F.M.M. (2010) Avaliação das Concentrações de Metais Traço nos Sedimentos do Parque dos Manguezais, Região Metropolitana do Recife (RMR), Pernambuco, Brasil. Tropical Oceanography, 38, 174-180.

[24] Oliveira, T.S., Barcellos, R.L., Schettini, C.A.F. and Camargo, P.B. (2014) Processo sedimentar atual e distribuição da matéria orgânica em um complexo estuarino tropical, Recife, PE, Brasil. Revista de Gestão Costeira Integrada, 14, 399-411. https://doi.org/10.5894/rgci470

[25] Aquino, E.P., Borges, G.C.P., Honorato-da-Silva, M., Passavante, J.Z.O. and Cunha, M.G.G.S. (2014) Microphytoplankton Community and Environmental Variables in an Urban Eutrophic Estuary (Capibaribe River, Northeast Brazil). Pan-American Journal of Aquatic Science, 9, 267-277.

[26] Manso, V.A.V., Coutinho, P.N., Guerra, N.C. and Silva Júnior, C.F.A. (2006) Pernambuco. In: Manso, V.A.V., Coutinho, P.N., Guerra, N.C., Eds., Erosão e progradação do litoral Brasileiro-Pernambuco, 179-196.

[27] IBGE (2010) Censo Demográfico 2010. Rio de Janeiro. http://censo2010.ibge.gov.br/

[28] Oliveira, T.S. (2014) Processo Sedimentar Atual e Distribuição da Matéria Orgânica no Sistema Estuarino dos Rios Capibaribe, Beberibe e Bacia do Pina (Recife-PE). Universidade Federal de Pernambuco, Recife.

[29] Carver, R. (1971) Procedures in Sedimentary Petrology. Wiley Interscience, New York.

[30] Folk, R.L. and Ward, W.C. (1957) A Study in the Significance of Grain-Size Parameters. Journal of Sedimentary Petrology, 27, 3-26. https://doi.org/10.1306/74D70646-2B21-11D7-8648000102C1865D

[31] Shepard, F.P. (1954) Nomenclature Based on Sand, Silt, Clay Rations. Journal of Sedimentary Petrology, 24, 151-158.

[32] Camargo, M.G. (2006) Sysgran: Um Sistema de Código Aberto para Análises Granulométricas do Sedimento. Revista Brasileira de Geociências, 36, 371-378.

[33] Saito, R.T., Figueira, R.C.L., Tessier, M.G. and Cunha, I.I.L. (2001) 210Pb and 137Cs geochronologies in the Cananeia-Iguape Estuary (São Paulo, Brasil). Journal of Radioanalytical and Nuclear Chemistry, 249, 257-261. https://doi.org/10.1023/A:1013219332322

[34] Patchineelam, S.R. and Smoak, J.M. (1999) Sediment Accumulation Rates along the Inner Eastern Brazilian Continental Shelf. Geo-Marine Letters, 19, 196-201. https://doi.org/10.1007/s003670050109

[35] Appleby, P.G. and Oldfield, F. (1978) The Calculation of Lead-210 Dates Assuming a Constant Rate of Supply of Unsupported ${ }^{210} \mathrm{~Pb}$ to the Sediment. CATENA, 5, 1-8.

[36] Figueira, R.C.L., Silva, L., Figueiredo, A. and Cunha, I. (1998) Goiana, Ten Years Later. Instrumental Analysis by Gamma Spectrometry of Low Level Cs-17 in Marine Samples. IAEA, 7, 327-329. 
[37] Skoog, D.A., Holler, F.J. and Nieman, T.A. (2009) Princípios de Análise Instrumental, $5^{\text {a }}$. Bookman, Porto Alegre.

[38] Baptista Neto, J.A., Smith, B.J. and McAllister, J.J. (2000) Heavy Metal Concentrations in Surface Sediments in a Nearshore Environment, Jurujuba Sound, Southeast Brazil. Environmental Pollution, 109, 1-9.

[39] Karageorgis, A.P., Katsanevakis, S. and Kaberi, H. (2009) Use of Enrichment Factors for the Assessment of Heavy Metal Contamination in the Sediments of Koumoundourou Lake, Greece. Water, Air, \& Soil Pollution, 204, 243-258. https://doi.org/10.1007/s003670050109

[40] Loring, D.H. (1991) Normalization of Heavy-Metal Data from Estuarine and Coastal Sediments. ICES Journal of Marine Science, 48, 101-115. https://doi.org/10.1093/icesjms/48.1.101

[41] Din, Z.B. (1992) Use of Aluminium to Normalize Heavy-Metal Data from Estuarine and Coastal Sediments of Straits of Melaka. Marine Pollution Bulletin, 24, 484-491.

[42] Grousset, F.E., Jouanneau, J.M., Castaing, P., Lavaux, G. and Latouche, C. (1999) A 70 Year Record of Contamination from Industrial Activity along the Garonne River and Its Tributaries (SW France). Estuarine Coastal and Shelf Science, 48, 401-414. https://doi.org/10.1006/ecss.1998.0435

[43] Covelli, S. and Fontolan, G. (1997) Application of a Normalization Procedure in Determining Regional Geochemical Baselines. Environmental Geology, 30, 34-45. https://doi.org/10.1007/s002540050130

[44] Szefer, P., Glasby, G.P., Kusak, A., Szefer, K., Jankowska, H., Wolowicz, M. and Ali, A.A.P. (1998) Evaluation of the Anthropogenic Influx of Metallic Pollutants into Puck Bay, Southern Baltic. Applied Geochemistry, 13, 293-304.

[45] Birch, G.F. and Olmos, M.A. (2008) Sediment-Bound Heavy Metals as Indicators of Human Influence and Biological Risk in Coastal Water Bodies. ICES Journal of Marine Science, 65, 1407-1413. https://doi.org/10.1093/icesjms/fsn139

[46] Hakanson, L. (1980) An Ecological Risk Index for Aquatic Pollution Control. A Sedimentological Approach. Water Research, 14, 975-1001.

[47] Satapathy, D.R. and Panda, C.R. (2015) Spatio-Temporal Distribution of Major and Trace Metals in Estuarine Sediments of Dhamra, Bay of Bengal, India-Its Environmental Significance. Environmental Monitoring and Assessment, 187, 4133. https://doi.org/10.1007/s10661-014-4133-7

[48] Larsonneur, C., Bouysse, P. and Auffret, J. (1982) The Superficial Sediments of the English Channel and Its Western Approaches. Sedimentology, 29, 851-864. https://doi.org/10.1111/j.1365-3091.1982.tb00088.x

[49] Turekian, K.K. and Wedepohl, K.H. (1961) Distribution of the Elements in Some Major Units of the Earth's Crust. Geology Society of America Bulletin, 72, 175-192. https://doi.org/10.1130/0016-7606(1961)72[175:DOTEIS]2.0.CO;2

[50] Alongi, D.M. (1990) Effect of Mangrove Detrital out Welling on Nutrient Regeneration, Oxygen Fluxes in Coastal Sediments of the Central Great Barrier Reef Lagoon. Estuarine Coastal and Shelf Science, 31, 581-598.

[51] Prasad, K.B.K., Dittmar, T. and Ramanathan, A.L. (2010) Organic Matter and Mangrove Productivity. In: Ramanathan, A.L., Bhattacharya, P., Dittmar, T., Prasad, M.B.K. and Neupane, B.R., Eds., Management and Sustainable Development of Coastal Zone Environments, Springer-Verlag, Berlin, 175-193.

https://doi.org/10.1007/978-90-481-3068-9_12

[52] Bosence, D.W.J. and Wilson, R.C.L. (2003) Carbonate Depositional system. In: The Sedimentary Record of Sea-Level Changes, Cambridge University Press, Cam- 
bridge, 209-233.

[53] Lana, P.C.M., Couto, E.C. and Almeida, M.V.O. (1997) Polychaete Distribution and Abundance in Intertidal Flats of Paranaguá Bay (SE Brazil). Bulletin Marine Science, 60, 433-442.

[54] Aloupi, M. and Angelidis, M.O. (2001) Geochemistry of Natural and Anthropogenic Metals in the Coastal Sediments of the Island of Lesvos, Aegean Sea. Environmental Pollution, 113, 211-219.

[55] Aprile, F.M. and Bouvy, M. (2010) Heavy Metal Levels in Surface Waters from a Tropical River Basin, Pernambuco State, Northeastern Brazil. Acta Scientiarum Biological Sciences, 32, 357-364. https://doi.org/10.4025/actascibiolsci.v32i4.5231

[56] Aprile, F.M. and Bouvy, M. (2008) Distribution and Enrichment of Heavy Metals in Sediments at the Tapacurá River Basin, North Eastern Brazil. Brazilian Journal Aquatic Science and Technology, 12, 1-8. https://doi.org/10.14210/bjast.v12n1.p1-8

[57] Alheiros, M.M. and Lima Filho, M.F. (1991) A Formação Barreiras. Revisão da faixa sedimentar costeira de Pernambuco, Paraíba e do Rio Grande do Norte. Série Estudos Geológicos, 10, 77-88.

[58] Barreiro, J.C. (2002) Imaginário e Viajantes no Brasil no século XIX: Cultura e Cotidiano, Tradição e Resistência. UNESP, São Paulo.

[59] Barros, S.A.L. and Leite, M.A.F.P. (2004) A Escala Bairro e o Conceito de Lugar Urbano: O Caso de Apipucos e Poço da Panela no Recife. Revista do Programa Pós-Graduação em Arquitetura e Urbanismo da FAUUSP, 15, 56-73. https://doi.org/10.11606/issn.2317-2762.v0i15p56-74

[60] Borborema, A.C.B.A., Andrade, H.J.L.F. and Sá, L.A.C.M. (2011) Da Cartografia dos antigos engenhos à cartografia holandesa e portuguesa. Anais do I simpósio Brasileiro de Cartografia Histórica, Paraty, 10-14 May 2011, 1-18.

[61] Freyre, G. (2004) Nordeste: Aspectos da influência da cana sobre a vida e a paisagem do Nordeste do Brasil, $7^{\text {a }}$. Global, São Paulo.

[62] Silva, L.M.T. (2007) Parahiba, uma Cidade Esquecida no Império oo Brasil (1822-1859). PhDThesis, Federal UniversityFluminense, Niterói.

[63] Liaghati, T., Preda, M. and Cox, M. (2003) Heavy Metal Distribution and Controlling Factors within Coastal Plain Sediments, Bells Creek Catchment, Southeast Queensland, Australia. Environmental. International, 29, 935-948.

[64] Pettijohn, F.J. (1975) Sedimentary Rocks. 2nd Edition, Harper \& Row, New York.

[65] Melo, V.M. (2005) Dinâmica de paisagens de rios urbanos. Anais do XI Encontro nacional da associação nacional de Pós-Graduação e Pesquisa em planejamento Urbano e Regional, Salvador, 23-27 May 2005, 1-20.

[66] Cesário, M.F.P. (2006) Um estudo da viabilidade do uso turístico do Rio Capibaribe no Recife. Msc Thesis, Universidade Federal de Pernambuco, Recife.

[67] Melo, J.G.S., Oliveira, T.H., Silva, C.A.V., Torres, M.F., Galvicio, J.D. and Silva, H.A. (2011) Análise espaço temporal do manguezal do baixo curso do rio Capibaribe, Recife-PE: Uma contribuição para o gerenciamento ambiental. $X V$ Simpósio Brasileiro de Sensoriamento Remoto, São José dos Campos, 30 April-5 May 2011, 6586-6593.

[68] Santos, F.M.M. (2010) Uso de geotecnologias para mapeamento de manguezais. Boletim Científico da ESMPU, 35, 137-156.

http://boletimcientifico.escola.mpu.mp.br/boletins/boletim-cientifico-n-35-julho-de zembro-de-2011/uso-de-geotecnologias-para-mapeamento-de-manguezais

[69] Zhang, L., Ye, X., Feng, H., Jing, Y., Ouyang, T., Yu, X., Liang, R., Gao, C. and Chen, W. (2007) Heavy Metal Contamination in Western Xiamen Bay Sediments 
and Its Vicinity, China. Marine Pollution Bulletin, 54, 974-982.

[70] Freire, G.S.S., Gomes, D.F., Lima, S.F., Maia, L.P. and Lacerda, L.D. (2004) Geochemistry of Continental Shelf Sediments of the Ceará Coast, North-Eastern Brazil. In: Lacerda, L.D., Santelli, R., Duursma, E. and Abrão, J.J., Eds., Environmental Geochemistry in Tropical and Subtropical Environments, Springer-Verlag, Berlin, 365-377. https://doi.org/10.1007/978-3-662-07060-4_26

[71] Aguiar, J.E., Lacerda, L.D., Miguens, F.C. and Marins, R.V. (2014) The Geostatistics of the Metal Concentrations in Sediments from the Eastern Brazilian Continental Shelf in Areas of Gas and Oil Production. Journal of South American Earth Sciences, 51, 91-104.

[72] Xu, Y., Sun, Q., Yi, L., Yin, X., Wang, A., Li, Y. and Chen, J. (2014) The Source of Natural and Anthropogenic Heavy Metals in the Sediments of the Minjiang River Estuary (SE China): Implications for Historical Pollution. Science Total Environment, 493, 729-736.

[73] CPRM (2005) Projeto Piloto Mapa Geoquímica Internacional.

[74] Coleman, M.L., Raiswell, R., Brown, A., Curtis, C.D., Aplin, A.C., Ortoleva, P.J., Gruszczynski, M., Lyons, T., Lovley, D.R. and Eglinton, G. (1993) Microbial Mineralization of Organic Matter-Mechanisms of Self Organization and Inferred Rates of Precipitation of Diagenetic Minerals. Philosophical Transaction the Royal Society London, A344, 69-87. https://doi.org/10.1098/rsta.1993.0076

[75] Morad, S., Ketzer, J.M. and De Ros, L.F. (2000) Spatial and Temporal Distribution of Diagenetic Alterations in Siliciclastic Rocks: Implication for Mass Transfer in Sedimentary Basin. Sedimentology, 47, 95-120.

https://doi.org/10.1046/j.1365-3091.2000.00007.x

[76] Curtis, C.D. (1987) Mineralogical Consequence of Organic Matter Degradation in Sediments: Inorganic/Organic Diagenesis. In: Legget, J.K. and Zuffa, G.G., Eds., Marine Clastic Sedimentology-Concepts and Case Studies, Graham and Troman Inc., Norwell, 108-123. https://doi.org/10.1007/978-94-009-3241-8_6

[77] Froelich, P.N., Klinkammer, M.L., Bender, M.L., Luedtke, N.A., Heath, G.R., Cullen, D. and Dauphin, P.P. (1979) Early Oxidation of Organic Matter in Pellagic Sediments of the Eastern Equatorial Atlantic: Suboxic Diagenesis. Geochimica et Cosmochimica Acta, 43, 1075-1090.

[78] Berner, R. (1981) A New Geochemical Classification of Sedimentary Environments. Journal Sedimentary Petrology, 51, 359-365.

[79] Mirlean, N., Baisch, P.R., Travassos, M.P. and Nassar, C. (2011) Calcareous Algae Bioclast Contribution to Sediment Enrichment by Arsenic on the Brazilian Subtropical Coast. Geo-Marine Letters, 31, 65-74. https://doi.org/10.1007/s00367-010-0215-x

[80] Mirlean, N., Medeanic, S., Garcia, F.A., Travassos, M.P. and Baish, P. (2012) Arsenic Enrichment in Shelf and Coastal Sediment of the Brazilian Subtropics. Continental Shelf Research,35, 129-136.

[81] Mirlean, N., Garcia, F., Baisch, P., Quintana, G.C. and Agnes, F. (2013) Sandy Beaches Contamination by Arsenic, a Result of Nearshore Sediment Diagenesis and Transport (Brazilian Coastline). Estuarine, Coastal and Shelf Science, 135, 241-247.

[82] Mirlean, N., Baisch, P. and Diniz, D. (2014) Arsenic in Grounwater of the Paraíba do Sul delta, Brazil: An Atmospheric Source? Science of the Total Environment, 482-483, 148-156.

[83] Mirlean, N., Baisch, P., Garcia, F., Seus, E. and Silva-Silveira, E. (2016) Coralline Algae and Arsenic Fixation in Nearshore Sediments. Regional Studies in Marine Science, 3, 83-88. 
[84] Wallner-Kersanach, M., Mirlean, N., Baumgarten, M.G.Z., Costa, L.F. and Baisch, P. (2016) Temporal Evolution of the Contamination in the Southern Area of the Patos Lagoon Estuary, RS, Brasil. Revista da Gestão Costeira Integrada, 16.

[85] Xavier, D.A., Barcellos, R.L., Figueira, R.C.L. and Schettini, C.A.F. (2016) Evolução sedimentar do estuário do rio Capibaribe (Recife-PE) nos últimos 200 anos e suas relações com a atividade antrópica e processo de urbanização. Tropical Oceanography, 44, 74-88.

Submit or recommend next manuscript to SCIRP and we will provide best service for you:

Accepting pre-submission inquiries through Email, Facebook, LinkedIn, Twitter, etc. A wide selection of journals (inclusive of 9 subjects, more than 200 journals) Providing 24-hour high-quality service

User-friendly online submission system Fair and swift peer-review system Efficient typesetting and proofreading procedure Display of the result of downloads and visits, as well as the number of cited articles Maximum dissemination of your research work

Submit your manuscript at: http://papersubmission.scirp.org/

Or contact ijg@scirp.org 